\title{
Sistem Informasi Penentuan Paket Pembelian Produk Menggunakan Algoritma Frequent Pattern-Growth Pada KPRI Jember
}

\author{
(Information System for Determining Purchase Package of Products Using \\ Frequent Pattern-Growth Algorithms) \\ Mohammad Ivan Noorkholid*), Muhammad Arief Hidayat, Gama Wisnu Fajarianto \\ Program Studi Sistem Informasi, Fakultas Ilmu Komputer, Universitas Jember \\ J1. Kalimantan 37 Jember 68121 \\ ${ }^{*}$ Penulis Korespondensi E-mail: ivanstoper97@gmail.com
}

\begin{abstract}
Abstrak
Penelitian ini bertujuan untuk merancang dan membangun sistem informasi penentuan paket pembelian produk pada KPRI Jember. Sistem ini menggunakan algoritma Fp-Growth (Frequent Pattern Growth) untuk menghasilkan informasi tentang paket pembelian produk dengan menangkap fenomena yang terjadi dalam transaksi penjualan. Implementasi algoritma Frequent Pattern Growth menggunakan PHP. Data hasil perhitungan algoritma Frequent Pattern Growth divisualisasikan dalam halaman website. Penerapan algoritma Frequent Pattern Growth didukung dengan metode association rules untuk menghasilkan data yang lebih lengkap dan akurat. Perhitungan membutuhkan data masukan berupa minimum support dan minimum confidence untuk memproses data transaksi penjualan menjadi paket pembelian produk. Dengan memasukkan minimum support 1 dan minimum confidence sebesar 50, hasil perhitungan didapatkan bahwa paket pembelian produk yang muncul sebanyak 10 paket dengan minimum support yang bermacam-macam berurutan dari produk pertama sampai produk terakhir. Semakin besar minimum support dan minimum confidence yang dimasukkan maka semakin sedikit paket pembelian produk yang dihasilkan.
\end{abstract}

Kata Kunci: strategi pemasaran, frequent pattern growth, association rules.

\section{Abstract}

This study aims to design and build information systems to determine product purchase packages in a cooperative. This system uses the Fp-Growth algorithm (Frequent Pattern Growth) to generate information about product purchase packages by capturing the phenomena that occur in sales transactions. Implementation of the Frequent Pattern Growth algorithm using PHP. Data from the calculation of the Frequent Pattern Growth algorithm are visualized on the website page. The application of the Frequent Pattern Growth Algorithm is supported by the association rules method to produce more complete and accurate data. The calculation requires input data in the form of minimum support and minimum confidence to process sales transaction data into a product purchase package. By entering minimum support 1 and minimum confidence of 50, the calculation results obtained by the product purchase package that appears as many as 10 packages with a minimum support of various sequences from the first product to the last product. The greater the minimum support and minimum confidence entered, the fewer packages for purchasing products produced.

Keywords: marketing strategy, frequent pattern growth, association rules.

\section{PENDAHULUAN}

Koperasi merupakan suatu bentuk perekonomian sebagai usaha bersama berdasarkan atas kekeluargaan. KPRI (Koperasi Pegawai Republik Indonesia) merupakan salah satu bentuk dari koperasi yang ada di Indonesia. Jember Memiliki beberapa KPRI, salah satunya adalah KPRI Universitas Jember. KPRI Universitas Jember memiliki beberapa usaha, salah satunya ialah unit pertokoan. Unit pertokoan ini memiliki beragam jenis produk dan juga memiliki harga yang bersaing. Beberapa mahasiswa lebih memilih berbelanja di KPRI Universitas Jember dengan alasan KPRI Universitas Jember Memiliki produk yang lengkap dan juga harganya tidak kalah saing dengan minimarket pada umumnya (Sugiyanto, 2015).

Saat ini perekonomian tengah berkembang dengan pesat. Persaingan dalam dunia bisnis mulai mengarah pada persaingan bebas yang semakin kompleks. Swalayan dan mini market semakin tidak terbendung kemunculannya.
Untuk mencapai hasil yang maksimal, konsumen harus ditempatkan pada posisi teratas, strategi pemasaran perlu diatur untuk mendapatkan hasil yang lebih efektif dan efisien.

Dalam menjalankan proses bisnis KPRI Universitas Jember Menggunakan sebuah sistem penjualan. Database konsumen yang tepat sasaran dan lengkap dapat digunakan sebagai senjata yang sangat ampuh bagi pelaku usaha. Database pelanggan dapat digunakan sebagai penunjuk arah penjualan, sebagai gambaran potensi pasar, untuk menganalisa penjualan, dan juga sebagai sarana komunikasi dengan konsumen (Warni, 2016). Salah satu strategi pemasaran yang dapat diterapkan dengan menggunakan database tersebut adalah strategi cross-selling produk untuk menentukan paket pembelian produk. Cross-selling merupakan teknik pemasaran yang dapat memikat konsumen untuk melengkapi produk awal yang telah dibeli dengan produk yang dapat melengkapinya. Cross-selling 
akan berhasil disaat konsumen mendapatkan nilai tambah. Menurut Ramaswarni cross-selling adalah salah satu seni dalam berjualan yang sangat menarik. Teknik ini memungkinkan terjadinya penjualan kembali setelah terjadi penjualan pertama, karena adanya keterkaitan kebutuhan (Kamakura, Ramaswami , \& R. K., 1991.).

Untuk mengembangkan strategi pemasaran pada KPRI Universitas Jember, maka dirancang sebuah sistem untuk menentukan paket pembelian produk yang merupakan salah satu strategi pemasaran produk. Database yang ada dalam sistem penjualan dapat digunakan sebagai data untuk menentukan paket pembelian produk untuk lebih memikat konsumen membeli barang lebih dari biasanya. Dengan diterapkannya strategi pemasaran ini diharapkan omset penjualan KPRI Universitas Jember juga semakin meningkat.

Dalam Penelitian ini korelasi antar produk satu dengan yang lainnya dari data penjualan produk KPRI Universitas Jember akan dianalisis menggunakan metode market basket analysis. Algoritma yang akan digunakan adalah Frequent Pattern Growth (FP-Growth). FP-Growth adalah salah satu dari beberapa algoritma yang dapat digunakan untuk menentukan data yang paling sering muncul (frequent itemset) dalam kumpulan data. Frequent itemset tersebut nantinya akan dijadikan sebagai acuan untuk merumuskan aturan-aturan asosiasi yang dihasilkan oleh model market basket analysis. Aturan-aturan asosiasi yang dihasilkan akan dianalisa dan di evaluasi untuk menemukan algoritma yang paling baik dan sesuai (best-fit algorithm) untuk permasalahan dalam penelitian ini. Menurut Bayu Adhi dalam penelitiannya yang membahas tentang penerapan strategi penjualan menggunakan association rules mengemukakan suatu hasil bahwa metode association rules berdampak langsung pada peningkatan revenue perusahaan. Data mining menjadi konsep yang berperan sangat penting untuk mengekstrak data transaksi menjadi informasi yang berguna yang didapatkan dari mengimplementasikan metode association rules (Tama, 2010).

Dinna Yunika (2018) melakukan sebuah penelitian yang membahas tentang pemakaian algoritma Frequent Pattern Growth (FP-Growth) dalam memberikan rekomendasi buku. Penelitian ini bertujuan untuk mengembangkan sistem informasi perpustakaan yang dilengkapi dengan fitur rekomendasi buku untuk memberikan referensi buku yang lain bagi anggota yang akan meminjam buku. Buku yang direkomendasikan merupakan buku yang memiliki kesamaan topic yang dibahas dengan buku yang dicari oleh anggota. Pengimplementasian algoritma FP-Growth ini pada sistem informasi perpustakaan terbukti berhasil dengan tampilnya rekomendasi buku sebanyak lima buah pada halaman pencarian. Rekomendasi ini berdasarkan hasil pencarian item set menggunakan FP-Tree dan hasil pencarian pola (rule) dengan mengetahui nilai support dan confident dari sebuah rule. Sedangkan pada penelitian Naufal Farras (2016) yang membahas tentang pengimplementasian algoritma FP-Growth pada analisa tingkat kelulusan mahasiswa Politeknik Negeri Malang membuktikan bahwa algoritma FP-Growth dapat digunakan untuk memberikan informasi tingkat kelulusan berdasarkan beberapa variable, serta dapat mengetahui tingkat kecocokan pekerjaan berdasarkan beberapa variable tertentu. Berdasarkan Uraian diatas, dengan penelitian ini, diharapkan dapat memberi hasil berupa informasi yang sagat bermanfaat bagi stakeholder, terutama yang berkaitan dengan strategi pemasaran dan penjualan, khususnya pada KPRI Universitas Jember.

\section{Tinjauan Pustaka}

\section{Market Basket Analysis}

Market basket analysis adalah metodologi yang digunakan untuk melakukan analisa buying habit atau kebiasaan membeli konsumen dengan menemukan asosiasi antara beberapa item yang berbeda, yang dibeli secara bersamaan atau dalam keranjang belanja yang sama (Gunaidi \& Sensue, 2012).

Market basket analysis menggunakan teknik matematis yang dipakai secara umum untuk mengungkap persamaan atau hubungan keterkaitan antara produk satu dengan yang lain. Market basket analysis menentukan produk apa yang dibeli bersamaan. Informasi yang didapat setelah mengetahui ketika satu produk akan dibeli bersamaan dengan produk lainnya dapat digunakan untuk memasarkan dan menjadikan pembeli produk tertentu sebagai target prospek untuk produk lainnya. Hal ini akan meningkatkan tingkat efektivitas taktik penjualan dan pemasaran dengan menggunakan data konsumen yang sudah tersedia (Marakas , 2003) .

Umumnya market basket analysis dimafaatkan sebagai titik awal untuk mencari strategi pemasaran yang efektif dengan cara mengetahui pola spesifik yang terlihat dari data transaksi yang sudah ada. Market basket analysis menghasilkan suatu aturan asosiasi (association rules). Asociation rules adalah pola-pola korelasi data dalam basis data.

\section{Association Rules}

Asociation rule merupakan teknik data mining yeng menjadi dasar dari berbagai metode data mining lainnya. Asociation rule digunakan untuk menentukan korelasi antar item dalam suatu kumpulan data (dataset) yang telah ditentukan. Pentingnya suatu aturan assosiatif dapat diketahui dengan dua parameter yaitu support (nilai penunjang) dan confidence (nilai kepastian). Support adalah prosentase kombinasi item tersebut dalam database sedagkan confidence adalah kuatnya hubungan antar item dalam aturan assosiatif. Analisis asosiasi didefinisikan sebagai suatu proses untuk menemukan semua suatu aturan assosiatif yang memenuhi syarat minimum untuk support (minimum support) dan juga syarat minimum untuk confidence (minimum confidence) (Pramudiono, 2003).

\section{FP-Growth}

FP-Growth merupakan salah satu algoritma data mining yang dapat digunakan untuk menentukan himpunan data mana saja yang paling sering muncul. Karakteristik algoritma FP-Growth adalah penjabaran struktur data menggunakan tree yang disebut FP-Tree. Dengan menggunakan FP-Tree, data dapat langsung diekstrak oleh FP-Growth untuk mendapatkan frequent itemset dari FPTree. Algoritma Frequent Pattern-Growth atau yang biasa disebut dengan FP-Growth merupakan pengembangan dari algoritma Apriori, sehingga dalam algoritma FP-Growth 
segala kekurangan dalam algoritma Apriori telah diperbaiki (Erwin, 2009).

\section{Analisa Pola Frekuensi Tinggi Dengan Algoritma Fp-} Growth

Frequent itemset dapat ditentukan dengan melakukan 2 proses yang harus dilakukan yaitu pembuatan FP-Tree dan penerapan FP-Growth untuk menemukan frequent itemset. Algoritma FP-Growth dapat mencari frequent itemset dengan memperluas penggunaan dari FP-Tree. Konstruksi FP-Tree dapat diliha pada Gambar 1.

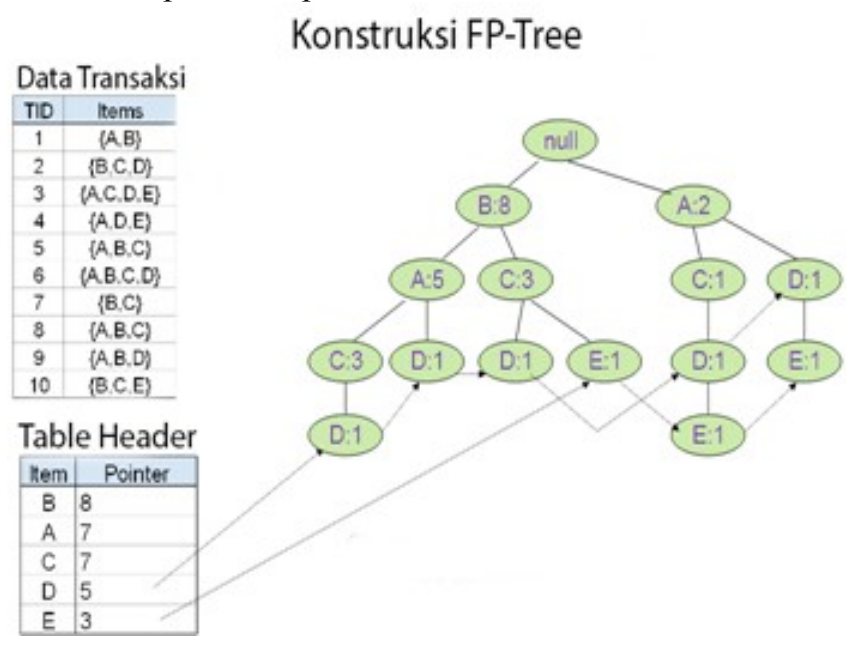

Gambar 1. Konstruksi Fp-Tree

\section{Pembuatan Fp-Tree}

FP-Tree merupakan struktur penyajian data yang dimampatkan. FP-Tree dibangun dengan memetakan setiap data transaksi menjadi lintasan data tertentu dalam FP-Tree. Dalam setiap transaksi, jika ada transaksi yang memiliki item yang sama, maka lintasan data dapat saling menimpa. Semakin banyak item yang sama dalam suatu transaksi, maka lintasan FP-Tree yang terbentuk semakin efektif (Gunaidi \& Sensue, 2012). Adapun definisi dari pohon FPTree sebagai berikut :

a. FP-Tree dibentuk oleh akar yang berlabel null, sekumpulan sub-tree yang berisi beberapa item tertentu yang sudah diurutkan berdasarkan frequensi munculnya item tersebut, dan sebuah tabel frequent header.

b. Dalam setiap simpul FP-Tree berisi tiga informasi penting, yaitu lebel item yang berisi informasi jenis item yang ada dalam simpul tersebut, support count yang berisi jumlah lintasan transaksi yang melalui simpul tersebut, dan pointer yang berfungsi sebagai penghubung antara simpulsimpul dengan label item sama antar lintasan, biasanya ditandai dengan garis panah putus-putus.

\section{Penerapan Algoritma Fp-Growth}

Setelah FP-Tree telah dibentuk, maka algoritma FPGrowth akan diterapkan untuk mencari frequent itemset yang signifikan. Algoritma FP-Growth memiliki tiga langkah utama, yaitu :

a. Pembangkitan Conditional Pattern Base

b. Pembangkitan Conditional FP-Tree

c. Pencarian frequent itemset

Pembentukan Aturan Asosiasi

Setelah menemukan pola frekuensi tinggi, maka langkah selanjutnya adalah mencari aturan asosiasi yang memenuhi syarat yang telah ditentukan. Untuk mendapatkan nilai support item A dapat diperoleh dari rumus sebagai berikut :

$$
S=\frac{\sum(\text { Transaksi item } A)}{\sum(\text { Transaksi })}
$$

Sementara itu untuk mencari nilai support dari 2 item dapat diperoleh dari rumus sebagai berikut :

$$
S(A, B)=\frac{\sum(\text { Transaksi item } A \text { dan } B)}{\sum(\text { Transaksi })}
$$

Sedangkan untuk nilai confidence nya dapat diperoleh dari rumus sebagai berikut :

$$
C(A, B)=\frac{\sum(\text { Transaksi item } A \text { dan } B)}{\sum(\text { Transaksi } A)}
$$

\section{METODE PENELITIAN}

\section{Jenis Penelitian}

Jenis penelitian yang dilakukan merupakan jenis penelitian kuantitatif karena jenis data dalam penelitian ini dalam bentuk angka yang bertujuan untuk medapat gambaran yang cukup jelas mengenai suatu keadaan data yang didapatkan dengan cara mengumpulkan, menyajikan dan menganalisa data tersebut sehingga data tersebut menjadi informasi yang lebih bermakna yang dapat digunakan untuk menganalisa masalah yang sedang diteliti.

\section{Tahapan Penelitian}

Penelitian ini secara garis besar dilakukan dengan beberapa tahapan yaitu penelitian diawali dengan pengumpulan data, kemudian dilanjutkan dengan perancangan sistem dan pembuatan laporan.

\section{Pengumpulan Data}

Pengumpulan data dilakukan untuk memperoleh data dan informasi yang dibutuhkan dan juga untuk memenuhi kebutuhan penelitian. Data yang digunakan penelitian ini berdasarkan sumber datanya terbagi menjadi dua yaitu data primer yang didapatkan dari hasil wawancara langsung ke pihak kpri unej dan data sekunder berupa informasi lain yang membantu dalam penelitian

\section{Perancangan Sistem}

Perancangan sistem menggunakan SDLC Waterfall. SDLC Waterfall adalah proses pengembangan perangkat lunak yang paling sederhana, umum digunakan dalam proyek-proyek perangkat lunak yang memiliki requirement yang sudah jelas. Model Ini adalah model sekuensial, sehingga ketika satu set kegiatan selesai maka aktivitas berikutnya dapat dimulai. Hal ini disebut Waterfall karena prosesnya mengalir "secara sistematis dari tahap satu ke tahap lainnya dalam mode ke bawah (Waterfall Model, 2017).

\section{Analisa Kebutuhan Sistem}

Pada tahap analisa kebutuhan sistem, yang pertama dilakukan adalah pendefinisian kebutuhan untuk merancang dan membangun sistem informasi penentuan paket pembelian produk KPRI Unej. Sekumpulan literatur yang telah didapat dianalisis untuk mendefinisikan kebutuhan sistem ke dalam kebutuhan fungsional dan kebutuhan non fungsional 


\section{Desain Sistem}

Tahapan ini menggambarkan desain sistem informasi dengan beberapa tahap yaitu business process, use case diagram, scenario, activity diagram, sequence diagram, class diagram, dan entity relationship diagram (ERD).

\section{Business process}

Business process merupakan diagram yang menggambarkan tentang kebutuhan data yang diperlukan oleh sistem. Skema input proses output sistem dapat dilihat pada Gambar 2.

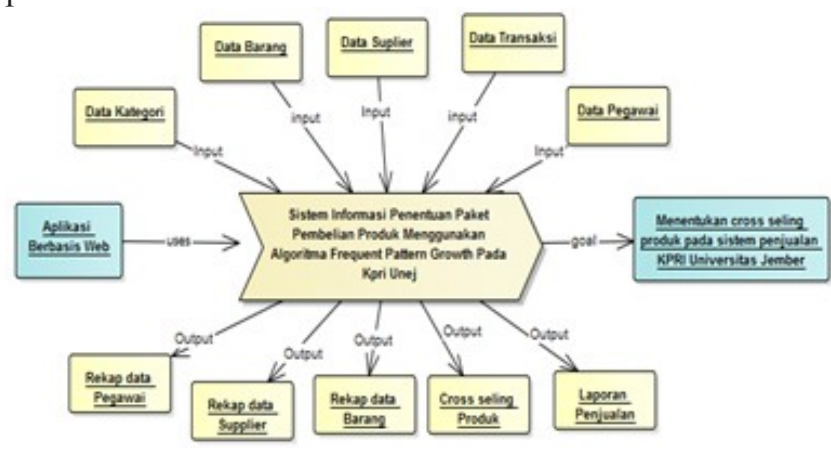

Gambar 2. Skema Input Proses Output Sistem

\section{Usecase Diagram}

Usecase diagram merupakan permodelan yanog dibuat untuk menggambarkan interaksi antara aktor dengan sistem yang akan dibangun. Dengan menggunakan Usecase diagram, peneliti dapat mengetahui interaksi yang bisa dilakukan antara aktor terhadap sistem sesuai dengan hak akses yang telah ditentukan. Usecase diagram sistem dapat dilihat ada Gambar 3

\section{Class Diagram}

Class diagram menggambarkan kelas-kelas dan juga hubungan antar kelas pada sistem yang nanti akan dibangun. Dalam kelas ada tiga komponen yaitu nama, operasi dan atribut. Nama berfungsi untuk memberi identitas pada suatu kelas, atribut berfungsi untuk memberi karakteristik pada data yang dipunya, sedangkan operasi bertujuan untuk memberikan sebuah fungsi ke sebuah objek.

\section{Entity Relationship Diagram}

Entity Relationship Diagram (ERD) merupakan dokumentasi yang menggambarkan struktur dan komponen database yang digunakan dalam membuat suatu sistem.

\section{HASIL DAN PEMBAHASAN}

Bab ini menjelaskan tentang sistem yang dihasilkan serta pembahasannya. Penelitian ini menghasilkan sebuah sistem informasi penentuan paket pembelian produk yang menggunakan algoritma Fp-Growth sebagai metode perhitungannya.

\section{Sistem Informasi Penentuan Paket Pembelian Produk}

Sistem informasi penentuan paket pembelian produk memiliki dua hak akses yaitu manajer dan pegawai. Bagian manajer memiliki dua fitur utama yaitu melihat paket pembelian produk dan juga manajemen pegawai. Pegawai memiliki beberapa fitur utama yaitu menambah data barang, menambah data kategori, menambah data supplier, dan menambah data penjualan. Tampilan utama sistem berbeda antara pegawai dan manajer.

Hasil Implementasi Algoritma Fp-Growth Pada Sistem

Implementasi algoritma Fp-Growth pada penelitian ini terdapat pada fitur analisa penjualan. Fitur ini dapat diakses oleh manajer. Dalam menggunakan fitur ini langkah pertama yang harus dilakukan adalah memasukkan datadata yang diperlukan untuk menajalankan algoritma tersebut seperti minimum support, minimum confidence dan jumlah transaksi.

Fitur analisa penjualan merupakan fitur yang menampilkan beberapa informasi tentang kecocokan antara produk satu dengan yang lain berdasarkan data penjualan yang telah ada. Pencarian pola asosiasi antar produk dipengaruhi oleh nilai support, nilai confidence serta banyaknya transaksi yang dimasukkan. Semakin besar nilai support dan confidence yang dimasukkan maka pola yang akan dibentuk akan semakin sedikit. Begitupula dengan data transaksi yang dimasukkan, semakin banyak data transaksi yang dimasukkan maka akan berpengaruh terhadap keakuratan sistem dalam memberikan informasi tentang kecocokan antar barang tersebut.

\section{Implementasi Algoritma $\boldsymbol{F p}$-Growth}

Implementasi algoritma $F p$-Growth terletak pada bagian fitur analisa penjualan. Data penjualan yang telah ada akan diambil beberapa untuk digunakan menjadi data masukan dalam melakukan analisa paket pembelian produk. Hasil pengambilan data penjualan kemudian diseleksi berdasarkan minimum support dan minimum confidence yang telah ditentukan. Analisa paket pembelian produk dapat dilakukan dengan memasukkan data minimum support, minimum confidence, dan jumlah transaksi.

Implementasi algoritma Fp-Growth pada sistem menghasilkan hasil yang sama dengan perhitungan manual.

Tabel 1. Perhitungan Manual

\begin{tabular}{clcc}
\hline Item & \multicolumn{1}{c}{ Item Set } & Support & Confidence \\
\hline 1 & $\begin{array}{l}\text { Pensil warna, Buku } \\
\text { Tulis }\end{array}$ & 0.25 & 0.50 \\
2 & Pensil warna, pensil & 0.25 & 0.50 \\
3 & Pensil warna, & 0.33 & 0.50 \\
& Bolpoin & 0 & 1.00 \\
4 & Pensil warna, Buku & 1.00 & \\
& Gambar & & \\
\hline
\end{tabular}

Banyaknya paket pembelian produk dipengaruhi oleh tinggi rendahnya nilai minimum support dan minimum confidence yang dimasukkan. Semakin besar nilai minimum support yang dimasukkan, maka akan semakin sedikit paket pembelian produk yang akan terbentuk. Begitupun dengan nilai minimum confidence yang dimasukkan, semakin besar nilai yang dimasukkan maka paket pembelian produk yang terbentuk akan semakin sedikit. Dalam perbandingan ini peneliti memasukkan jumlah transaksi yang sama namun support dan confidence yang berbeda 


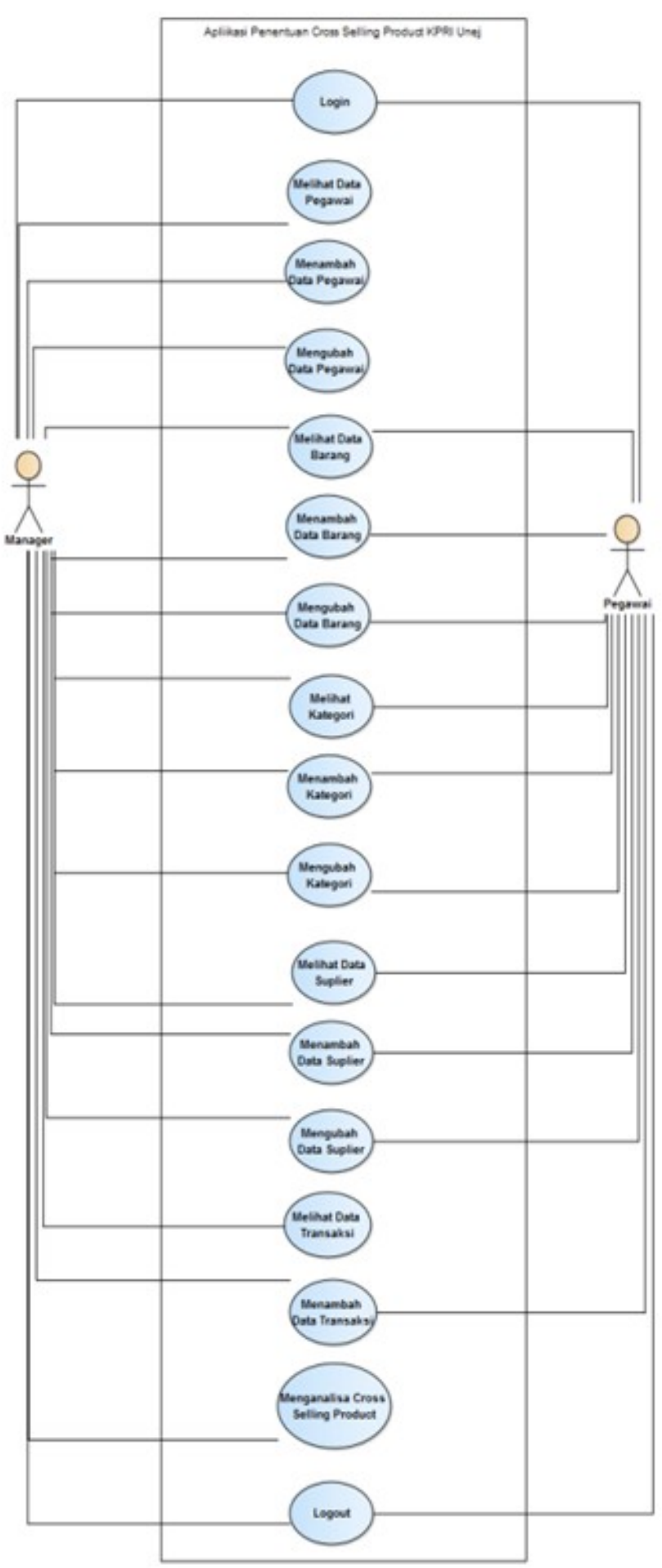

Gambar 3. Use Case Diagram

Tabel 2. Inputan Percobaan

\begin{tabular}{cccc}
\hline Percobaan & $\begin{array}{c}\text { Minimum } \\
\text { Support }\end{array}$ & $\begin{array}{c}\text { Minimum } \\
\text { Confidence }\end{array}$ & $\begin{array}{c}\text { Jumlah } \\
\text { Transaksi }\end{array}$ \\
\hline 1 & 1 & 50 & 5 \\
2 & 1 & 60 & 5 \\
3 & 1 & 70 & 5 \\
4 & 2 & 50 & 5 \\
5 & 3 & 50 & 5 \\
\hline
\end{tabular}

Percobaan pertama minimum support yang dimasukkan ke dalam sistem untuk menghasilkan paket pembelian produk adalah 1 . Sedangkan minimum confidence yang dimasukkan adalah 50 dengan data transaksi sama pada semua percobaan yaitu 5 data transaksi. Hasil percobaan 1 ditunjukkan pada tabel 3 .

Tabel 3. Hasil Percobaan 1

\begin{tabular}{|c|c|c|c|}
\hline Item & Association Rules & Support & Confidence \\
\hline 1 & $\begin{array}{l}\text { Jika membeli Pensil } \\
\text { Warna, maka akan } \\
\text { membeli Buku Tulis }\end{array}$ & 0.25 & 0.50 \\
\hline 2 & $\begin{array}{l}\text { Jika membeli Pensil } \\
\text { Warna, maka akan } \\
\text { membeli Pensil }\end{array}$ & 0.25 & 0.50 \\
\hline 3 & $\begin{array}{l}\text { Jika membeli Pensil } \\
\text { Warna, maka akan } \\
\text { membeli Bolpoin }\end{array}$ & 0.33 & 0.50 \\
\hline 4 & $\begin{array}{l}\text { Jika membeli Pensil } \\
\text { Warna, maka akan } \\
\text { membeli Buku } \\
\text { Gambar }\end{array}$ & 1.00 & 1.00 \\
\hline 5 & $\begin{array}{l}\text { Jika membeli Buku } \\
\text { Gambar, maka kakan } \\
\text { membeli Buku Tulis }\end{array}$ & 0.25 & 0.50 \\
\hline 6 & $\begin{array}{l}\text { Jika membeli Buku } \\
\text { Gambar, maka akan } \\
\text { membeli pensil }\end{array}$ & 0.25 & 0.50 \\
\hline 7 & $\begin{array}{l}\text { Jika membeli Buku } \\
\text { Gambar, maka akan } \\
\text { membeli Bolpoin }\end{array}$ & 0.33 & 0.50 \\
\hline 8 & $\begin{array}{l}\text { Jika membeli } \\
\text { Bolpoin, maka akan } \\
\text { membeli Buku Tulis }\end{array}$ & 0.67 & 1.00 \\
\hline 9 & $\begin{array}{l}\text { Jika membeli } \\
\text { Bolpoin, maka akan } \\
\text { membeli pensil }\end{array}$ & 0.25 & 0.50 \\
\hline 10 & $\begin{array}{l}\text { Jika membeli pensil, } \\
\text { maka akan membeli } \\
\text { Buku Tulis }\end{array}$ & 0.50 & 0.67 \\
\hline
\end{tabular}

Percobaan kedua menggunakan minimum support sama dengan percobaan 1 sedangkan minimum confidence memiliki nilai yang berbeda yaitu sebesar 60. Hasil yang diperoleh pada pecobaan kedua dapat dilihat di tabel 4 .

Tabel 4. Hasil Percobaan 2

\begin{tabular}{|c|c|c|c|}
\hline Item & Association Rules & Support & Confidence \\
\hline 1 & $\begin{array}{l}\text { Jika membeli Pensil } \\
\text { Warna, maka akan } \\
\text { membeli Buku } \\
\text { Gambar }\end{array}$ & 1.00 & 1.00 \\
\hline 2 & $\begin{array}{l}\text { Jika membeli } \\
\text { Bolpoin, maka akan } \\
\text { membeli Buku Tulis }\end{array}$ & 0.67 & 1.00 \\
\hline 3 & $\begin{array}{l}\text { Jika membeli Pensil, } \\
\text { maka akan membeli } \\
\text { Buku Tulis }\end{array}$ & 0.50 & 0.67 \\
\hline
\end{tabular}


Hasil dari setiap percobaan memiliki perbedaan antara satu dengan yang lainnya. Hal ini terjadi karena inputan dari beberapa percobaan tersebut tidak sama. Perbandingan penentuan paket pembelian yang terbentuk menggambarkan bahwa nilai minimum support dan minimum confidence sangat berpengaruh terhadap banyaknya paket pembelian produk yang terbentuk meskipun dengan data transaksi yang sama. Semakin besar nilai yang dimasukkan pada minimum support maupun minimum confidence akan berdampak pada semakin sedikitnya paket pembelian produk yang akan terbentuk

\section{Perancangan dan Pembangunan Sistem}

Sistem informasi penentuan paket pembelian produk digunakan sebagai penunjang keputusan untuk merancang strategi pemasaran pada KPRI UNEJ. Paket pembelian produk yang terbentuk digunakan sebagai acuan untuk membuat promosi barang guna meningkatkan omset penjualan. Promosi dilakukan dengan melihat korelasi antar barang satu dengan barang yang lain dari hasil pencarian pola penjualan. Sistem dibangun untuk mempermudah proses pencarian pola penjualan yang akan dijadikan paket pembelian produk dan menentukan barang mana yang akan dipromosikan dengan lebih cepat dan akurat.

Pembangunan sistem dimulai dengan membangun fitur utama yang ada dalam sistem. Sistem memiliki dua hak akses yaitu pegawai dan manajer. Pegawai dapat mengakses beberapa fitur seperti mengelola data produk, mengelola data supplier, mengelola data kategori, dan melakukan transaksi penjualan. Manajer memiliki fitur khusus yang tidak bisa diakses oleh pegawai yaitu mengelola data pegawai dan menggunakan fitur analisa penjualan untuk mendapatkan informasi tentang paket pembelian produk.

\section{KESIMPULAN}

Algoritma Fp-Growth dapat diimplementasikan dengan memasukkan beberapa variabel seperti minimum confidence, minimum support dan jumlah transaksi yang akan dianalisis. Data paket pembelian produk yang dihasilkan dari algoritma Fp-Growth dapat dijadikan acuan sebagai strategi penjualan dengan memberikan pilihan paket pembelian pada konsumen. Banyaknya paket pembelian produk yang dihasilkan dipengaruhi oleh besarnya nilai minimum support dan minimum confidence yang dimasukkan. Semakin besar nilai minimum support dan minimum confidence yang dimasukkan maka paket pembelian produk yang terbentuk akan semakin sedikit.

Pengembangan sistem informasi penentuan paket pembelian produk dibangun dengan basis website dengan dua hak akses yaitu pegawai dan manajer. Manajer memiliki akses terhadap fitur utama yaitu menganalisa data penjualan untuk menentukan paket pembelian produk. Sistem dikembangkan dengan mengadopsi SDLC Waterfall. Model waterfall sangat cocok untuk mengembangkan sistem ini karena memiliki proses yang urut dan juga data yang dibutuhkan sudah memiliki rincian yang tidak berubah dari awal pembuatan sampai penyelesaian program. Data yang dibutuhkan oleh sistem adalah data transaksi, data minimum support dan data minimum confidence sebagai data masukan untuk menentukan paket pembelian produk.

\section{SARAN}

Pemanfaatan perhitungan algoritma Fp-growth pada sistem ini hanya sampai pada proses penentuan paket pembelian produk, namun akan lebih baik jika terdapat fitur yang bisa melacak keefektifan paket pembelian produk yang dihasilkan sehingga paket pembelian produk yang dihasilkan dapat dipantau keberhasilannya.

Proses penentuan paket pembelian produk dapat dilakukan dengan menggunakan metode atau algoritma lain dengan objek penelitian yang sama. Penentuan paket pembelian produk dengan menggunakan algoritma $F p$ Growth juga dapat lebih dikembangkan dengan menggabungkan dengan metode lain yang saling mendukung.

\section{DAFTAR PUSTAKA}

[1] (2017, 08 14). Retrieved from Waterfall Model: http://www.waterfall-model.com/.

[2] Erwin. (2009). Analisis Market Basket Dengan Algoritma Apriori dan FP-Growth. Jurnal Generic.

[3] Gunaidi, G., \& Sensue, D. I. (2012). Penerapan Metode Data Mining Market Basket Analysis Terhadap Data Penjualan Produk Buku dengan Menggunakan Algoritma Apriori dan Frequent Pattern Growth (FP-GROWTH) Studi Kasus Percetakan PT. Gramedia.

[4] Marakas , M. (20003). Modern Data Warehousing, Mining, And Visualization.

[5] Pramudiono, I. (2003). Menambang Permata Pengetahuan di Gunung Data.

[6] Syaifullah, M. A. (2010). Implementasi Data Mining Algoritma Apriori Pada Sistem Penjualan. Yogyakarta: STMIK AMIKOM.

[7] Turban, E. A. (2005). Sistem Pendukung Keputusan dan Sistem Cerdas. Yogyakarta: Andi. 